\title{
Studies on the Propagation of Jamaican Ackee (Blighia sapida L.) by Air-layering
}

\author{
Rajendra P. Maurya ${ }^{1}$, Dion M. Lewis, and Jeff St. A. Chandler \\ Department of Biological and Chemical Sciences (Faculty of Science and \\ Technology), The University of the West Indies, Cave Hill Campus, P.O. Box \\ 64, Bridgetown, Barbados, West Indies
}

Additional index words. air-layering, Blighia sapida, indole-3-butyric acid, IBA, propagation

Abstract. This study was conducted to determine the effects of indole-3-butyric acid (IBA) on the air-layering propagation of Jamaican ackee (Blighia sapida L.). Blighia sapida $\mathrm{L}$. is a woody perennial, evergreen multipurpose fruit tree species native to the Guinean forests of West Africa. The fleshy arils of the ripened fruits are edible. All selected mother plants were fully grown mature, vigorous, healthy, and disease-free trees located within the landscape at The University of the West Indies, Cave Hill Campus. The experiment was laid out as a randomized block design with five different concentrations of the rooting hormone $(0,2000,2500,3000$, and $3500 \mathrm{ppm})$ IBA and individual trees as blocks. The highest $(100 \%)$ rooting success, maximum (108.0) number of roots, longest $(16.0 \mathrm{~cm})$ root length, and maximum (11.9 g) fresh weight and (3.7 g) dry weight of roots per stem were recorded in the treatment of $3500 \mathrm{ppm}$ IBA. The results of this study can benefit fruits and nursery growers interested in propagating true-to-type Blighia sapida plants.

Jamaican Ackee (Blighia sapida L.) is a woody perennial, evergreen tree, which belongs to the family Sapindaceae. It was named Blighia sapida in honor of Captain William Bligh who in 1793 took plant samples to Kew Gardens in South London (Lancashire, 2004; Lewis, 1965). This plant is originally from West Africa and was introduced to the West Indies during the 18th century. It is presently found in many Caribbean countries including Barbados, Jamaica, Trinidad, and Haiti. The Jamaican ackee is a tropical to subtropical plant and tends to grow well in average, welldrained soil. It prefers full sunlight and blooms during warm months. It attains $\approx 6$ to $12 \mathrm{~m}$ in height, and branches are organized in a spreading formation, which results in a dense crown cover. Leaves are pinnate with six to 10 leaflets, which are obviate in shape and 10 to $15 \mathrm{~cm}$ in length. Flowers are small and composed of five petals, and fruits are ovoid and green in color. Fruits also have a leathery skin texture and are borne in clusters, turn red, and split into three or four valves at ripening. Splitting exposes cream yellow arils, a red funicle, and glossy black seeds (Llamas, 2003).

\footnotetext{
Received for publication 13 May 2013. Accepted for publication 20 Aug. 2013.

We thank Dean, Faculty of Science and Technology, and Head, Department of Biological and Chemical Sciences, for providing facilities to conduct this research. We also thank Mr. Martin Warrington (Manager of Properties and Facilities, Cave Hill Campus) for allowing us to use the Jamican ackee trees located on the campus and Dr. Francis B. Lopez for statistical analysis and data interpretation of this research. In addition, we also thank Devon Slator and Andrew Harewood for their assistance.

${ }^{1}$ To whom reprint requests should be addressed; e-mail rajendra.maurya@cavehill.uwi.edu.
}

cutting and air-layering propagations can be alternative methods for producing true-totype and inexpensive plants.

Air-layering is the initiation of adventitious root growth on a stem, which is attached to the mother plant until root formation. It is used for a wide variety of plant species, especially those that are difficult to initiate root growth using cuttings (Hartmann et al., 2002). The application of root-promoting substances such as auxins helps in the stimulation of root development and increases uniformity of rooting. This in turn results in the propagating of new plants in a shorter period of time and low cost. IBA is one of the most effective and widely used auxins in vegetative propagation (Blazich, 1988; Dirr and Heuser, 2006; Hartman et al., 2011). It is non-toxic to plants over a wide range of concentrations and is effective in stimulating root growth in a large number of plant species (Hartmann et al., 2002). The objective of this research was to determine the optimum concentration of growth regulator to enhance rooting percentage of the stems that were air-layered.

\section{Materials and Methods}

Blighia sapida L. is most popular in Jamaica where it is considered as the national fruit and is consumed in the Jamaican national dish called Ackee and Salt fish. This dish includes a mixture of fruit arils and cod fish. Arils from ripe fruits are also processed in brine, canned, and exported to the United Kingdom (Morton, 1987). The popularity of this evergreen tree is also increasing in Barbados, where it is used in landscaping and fruits are used in several Barbadian dishes.

The fruits of Jamaican ackee are a good source of purified oil and have a high nutritive value and thus make up an important portion of the fatty acid intake of those who consume the fruit. In addition, fruits also contain protein, calcium, potassium, and vitamins (Lancashire, 1995). In Africa, mature arils are eaten raw or in soup and are also fried in oil (Morton, 1987). This plant is used in traditional folk medicine in Brazil where repeated small doses of an aqueous extract of the seed have been used to expel parasites (Morton, 1987). In Cuba, a mixture of ripe arils, sugar, and cinnamon is used to treat dysentery. The bark is used in the preparation of an ointment for pain relief in the Ivory Coast (Morton, 1987).

Trees are most commonly propagated by seeds but seedling plants are not true-to-type and result in fruits of varying size and quality (Crane and Balerdi, 2008). Seeds are affected by desiccation and are considered shortlived. In addition, they can take as long as 2 to 3 months to germinate and as many as 6 years for fruit bearing (Crane and Balerdi, 2008). Other propagation techniques that can be used include budding, grafting, cuttings, and air-layering. The production of seedlings for rootstock is required for budding and grafting and this makes these methods timeconsuming and expensive. As a result of the great demand for true-to-type plants, stem
The present investigation was conducted at the University of the West Indies, Cave Hill Campus during the period Sept. to Nov. 2011.

Five concentrations of the rooting hormone IBA $(0,2000,2500,3000$, and $3500 \mathrm{ppm})$ were used in this study. The required amount of IBA needed for each concentration was weighed by microbalance and placed into the respectively labeled bottle and $1 \mathrm{~N} \mathrm{NaOH}$ was then added to each bottle as a solvent, and the bottles were individually swirled and shaken until all of the particles had dissolved. Distilled water was used in control. Four mature trees that were $\approx 7$ years old and were vigorous, healthy and free from insect pests and diseases were selected for this study. Each individual plant was considered as a separate block. Previous-season-old branches, which were $\approx 1.0$ to $1.5 \mathrm{~cm}$ in diameter and exterior in the canopy, were chosen for airlayering. To perform air-layering, a total of 50 stems was selected from all directions on each healthy tree and 10 stems were airlayered per treatment. Using a budding knife, the leaves around the area, which was to be air-layered, were removed. The stem was girdled by making a cylindrical cut, which was $\approx 3.0 \mathrm{~cm}$ in length just below the node, and the entire strip of bark was peeled away. The strips of absorbent cotton were soaked in beakers containing the different concentrations of IBA. One cotton strip soaked with growth hormone was taken from a beaker and wrapped around the upper region of the ring of the girdled area. It was then covered with moist promix, which was placed on a piece of aluminum foil and placed around the treated region as well as a girdled part of the stem and the entire length of the foil was securely wrapped around the stem. The covered area was then gently squeezed to remove air, 
which may have been trapped during the wrapping process (Hartman et al., 2011). One treatment was done at a time and labeled indicating treatment name, block number, and date. The procedure was repeated using all treatments on all four trees. Three weeks after stems were air-layered, a few stems were examined for rooting by carefully unwrapping the aluminum foil to expose the roots. Five weeks after treatment application, all stems were removed from the mother trees and examined. All air-layered stems were arranged according to their treatment and placed into five bundles of each block. The observations like percentage of air-layering success, number of roots, longest root length $(\mathrm{cm})$, and fresh and dry weight of roots $(\mathrm{g})$ were recorded in the laboratory and averaged for each treatment in each block.

The roots were counted and removed from stem to measure the weight. All roots were placed on aluminum foil and fresh weight was determined on a microbalance, following which the aluminum foil was folded and samples placed in an oven at $80{ }^{\circ} \mathrm{C}$ for $5 \mathrm{~d}$. The dry weight $(\mathrm{g})$ was recorded for all treatments after cooling in a desiccator for $2 \mathrm{~h}$. The mean values of all parameters were statistically analyzed using GenStat (4th edition; VSN International, U.K.).

\section{Results and Discussion}

A significant effect on air-layering success was observed in all treatments over the control, but no significant differences were observed within the IBA treatments. The application of auxins such as IBA is known to promote the development of adventitious roots and uniformity among percent rooting success (Hartmann et al., 2002). It was therefore expected that better root formations would have been observed in air-layering treatments with the higher concentrations of IBA, 3000 and $3500 \mathrm{ppm}$. The highest survival percentage of air-layers $(100 \%)$ was recorded for air-layered stems treated with $3000 \mathrm{ppm}$ and $3500 \mathrm{ppm}$ IBA, and the lowest $(35 \%)$ percent rooting was observed in the control. The significant difference was observed among all treatments over the control (Table 1). Dhua and Sen (1984) and Lingarajappa (1982) have reported similar results in jackfruit air-layering. The present findings regarding the effect of IBA is in agreement with that of Mukhopadhaya (1986) who reported the increasing trend for rooting and survival up to $2500 \mathrm{ppm}$ and the lowest survival of litchi air-layering in control. The findings of Borah and Das (2000) are also in close conformity.

These results could be attributed to a number of factors, for example the accumulation of photosynthetic products such as carbohydrates just above the girdled area of the stem, which would influence the development of root growth (Davies, 1988). This is one of the many benefits of air-layering and occurs because removal of the phloem prevents the continuous flow of materials throughout the stem. The use of IBA directly promotes rapid cell division and elongation but also aids in the use of IBA, all of which would have promoted root development (Taiz and Zeiger, 2006). The health and vigor of the trees that were used could have also played a significant role (Hartmann et al., 2002). Trees were mature, vigorous, pest- and disease-free, and during the time of air-layering trees were not in the peak fruiting phase. As a result, photosynthetic products such as carbohydrates produced by the plant would have been available to be used by the stems to enhance rooting rather than being redirected to other areas such as flowering and fruiting. In addition, during the time of stem attachment and thus root formation, there was an average to moderate level of rainfall of $160 \mathrm{~mm}$ per month. The mean monthly temperatures ranged between 22 and $30.5^{\circ} \mathrm{C}$. The relative humidity ranged between $73 \%$ and $80 \%$ during Sept. to Dec. 2011 in Barbados (Table 2). This temperature range, high rainfall, and relative humidity enhanced ideal air-layering success in Jamaican ackee because the parent plant would have been exposed to a continuous supply of moisture (Hartmann, 1969). This would have had an impact on the airlayered stem because the parent plant would have been able to sustain its vigor, and there would have been a reduction in the occurrence of stress as a result of drought or a lack of moisture. The parent plant would have therefore been able to maintain all internal processes, which would have ensured a continuous supply of products and sustenance of the stem while it was still attached (Taiz and Zeiger, 2006).

Another influential factor may have been the time in which air-layering was done. Rahman et al. (2002) reported that time had a noticeable effect on rooting and survival of air-layered stems of litchi (Litchi chinensis) and that maximum results were observed for layers prepared in the rainy season. This is supported by Maiti (1985) who reported that the best time to prepare air-layers of litchi is at the beginning of the rainy season. This is significant because litchi is a member of the same family as the Jamaican ackee (Sapindaceae). Furthermore, stems were airlayered in the rainy season, which coincides with the more suitable time reported by Maiti (1985) and Rahman et al. (2002).

There was a consistent and significant increase in the number of roots observed per stem as the concentration of IBA rooting hormone increased. The maximum (108.0) number of roots was observed in $3500 \mathrm{ppm}$ IBA followed by 73.2 in 3000 ppm IBA and the least (7.2) roots in the control (Table 2). A significantly lower number of roots was recorded for the control in comparison with all other treatments (Fig. 1). There was a positive relationship between the number of roots and the concentration of IBA used; an increase in concentration resulted in an increase in the number of roots and a significant difference was observed within treatments. This would have been the result of the effects of IBA on the promotion of roots (Taiz and

Table 1. Effect of indole-3-butyric acid (IBA) concentrations on rooting percentage, number of roots, and fresh and dry weight of roots. ${ }^{\mathrm{z}}$

\begin{tabular}{lccccc}
\hline Treatments & $\begin{array}{c}\text { Rooting } \\
\text { per cent }\end{array}$ & $\begin{array}{c}\text { Number of roots } \\
\text { per stem }\end{array}$ & $\begin{array}{c}\text { Length of longest } \\
\text { root }(\mathrm{cm})\end{array}$ & $\begin{array}{c}\text { Fresh wt of } \\
\text { roots }(\mathrm{g})\end{array}$ & $\begin{array}{c}\text { Dry wt of } \\
\text { roots }(\mathrm{g})\end{array}$ \\
\hline Control & $35 \mathrm{a}$ & $7.2 \mathrm{a}$ & $11.6 \mathrm{a}$ & $0.7 \mathrm{a}$ & $0.2 \mathrm{a}$ \\
IBA 2000 ppm & $90 \mathrm{~b}$ & $40.0 \mathrm{~b}$ & $13.4 \mathrm{ab}$ & $2.1 \mathrm{a}$ & $0.5 \mathrm{a}$ \\
IBA 2500 ppm & $93 \mathrm{~b}$ & $52.8 \mathrm{bc}$ & $14.2 \mathrm{ab}$ & $1.9 \mathrm{a}$ & $0.6 \mathrm{a}$ \\
IBA 3000 ppm & $100 \mathrm{~b}$ & $73.2 \mathrm{c}$ & $15.3 \mathrm{~b}$ & $4.3 \mathrm{~b}$ & $1.2 \mathrm{~b}$ \\
IBA 3500 ppm & $100 \mathrm{~b}$ & $108.0 \mathrm{~d}$ & $16.0 \mathrm{~b}$ & $5.2 \mathrm{~b}$ & $1.6 \mathrm{~b}$ \\
\hline
\end{tabular}

${ }^{\mathrm{z}}$ Means of 10 air-layered stems. In each column, means with a common attached letter are not significantly different $(P \geq 0.05)$ from each other by the least significant difference (LSD) test.

Table 2. Mean monthly temperature, relative humidity, and total precipitation and rain days per month in Barbados during 2011.

\begin{tabular}{|c|c|c|c|c|c|}
\hline \multirow[b]{2}{*}{ Months } & \multicolumn{2}{|c|}{ Temperature $\left({ }^{\circ} \mathrm{C}\right)$} & \multirow[b]{2}{*}{ Precipitation $(\mathrm{mm})$} & \multirow[b]{2}{*}{ Rain days } & \multirow[b]{2}{*}{ Relative humidity (\%) } \\
\hline & Minimum & Maximum & & & \\
\hline September & 23.0 & 30.0 & 160 & 16 & 73.0 \\
\hline October & 23.5 & 30.5 & 170 & 16 & 76.5 \\
\hline November & 22.0 & 28.5 & 210 & 17 & 80.0 \\
\hline
\end{tabular}

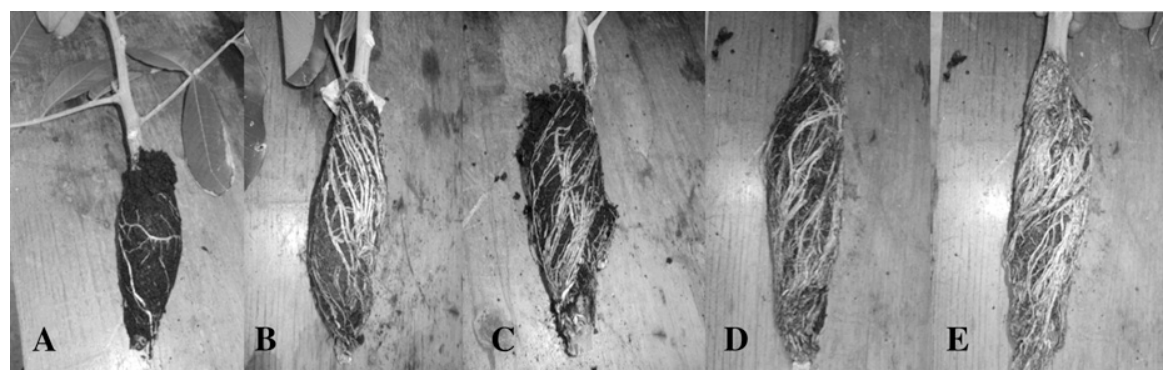

Fig. 1. Comparison of the effect of indole-3-butyric acid (IBA) concentrations on rooting after 5 weeks. (A) Control, (B) 2000 ppm, (C) 2500 ppm, (D) 3000 ppm, and (E) 3500 ppm. 
Zeiger, 2006). Therefore, the higher the concentration, the more hormones would have been present and the greater the stimulation of root production. A faster response to the promotion of root development would have also been initiated. This was evident in the quality and maturity of roots observed for each treatment (Fig. 1).

The longest $(16.0 \mathrm{~cm})$ root was observed in $3500 \mathrm{ppm}$ IBA followed by $15.3,14.2$, and $13.4 \mathrm{~cm}$ in $3000 \mathrm{ppm}, 2500 \mathrm{ppm}$, and 2000 ppm IBA, respectively (Table 1), although the shortest $(11.6 \mathrm{~cm})$ root length was observed in the control. However, there was no significant difference in the length of roots observed within the different IBA concentrations and the control. There were minimal differences in the length $(\mathrm{cm})$ of the longest root obtained for each treatment. However, a gradual increase was noticed. This resulted in the shortest root in the control and the longest root was recorded in $3500 \mathrm{ppm}$ IBA (Table 1). Again, this could have been the result of the differences in IBA concentrations present in each treatment.

The highest $(5.2 \mathrm{~g})$ root fresh weight was recorded in 3500 ppm IBA followed by $4.3 \mathrm{~g}$ in 3000 ppm IBA. No significant differences were observed between $3500 \mathrm{ppm}$ and $3000 \mathrm{ppm}$ IBA. Also, both treatments showed significant differences over the control, $2000 \mathrm{ppm}$, and $2500 \mathrm{ppm}$ IBA. The maximum dry weights of $1.6 \mathrm{~g}$ and $1.2 \mathrm{~g}$ were also recorded in $3500 \mathrm{ppm}$ and $3000 \mathrm{ppm}$ IBA, respectively. Likewise, the same trend was observed for the dry weight of roots (Table 1). This would have corresponded with the trend observed in the number of roots recorded, whereby as the concentration increased, so too did the number of roots. Therefore, the higher number of roots, the greater the weight. Again, similarities in rooting percentage at all concentrations tested were noticed between 2000 and 3500 ppm IBA over the control. A similar trend was reported by Rahman et al. (2000) for Litchi chinensis, whereby the highest air-layering success, maximum number of roots, and root length were recorded for $2500 \mathrm{ppm}$ IBA and the minimum in the control.

\section{Conclusion}

Based on the results obtained for this research project, it can be concluded that air-layering is a suitable vegetative propagation technique for the production of true-totype plants of Blighia sapida L. Although there were similarities in rooting percentage at all concentrations tested between $3000 \mathrm{ppm}$ and $3500 \mathrm{ppm}$ IBA, it is recommended that 3500 ppm IBA be used because this rate yields a greater number of roots and root fresh and dry weight.

\section{Literature Cited}

Blazich, F.A. 1988. Chemical and formulations used to promote adventitious rooting, p. 132 149. In: Davis, T.D., B.E. Haissig, and N. Sankhla (eds.). Adventitious root formation in cuttings. Dioscorides Press, Portland, OR.

Borah, A. and R.P. Das. 2000. Efficiency of indole3-butyric acid (IBA) on rooting of stem cuttings of some minor fruits of Assam. Haryana J. Hort. Sci. 29:196-198.

Crane, J.H. and C.F. Balerdi. 2008. Ackee growing in the Florida home landscape. University of Florida. Original publication date Jan. 2008. Reviewed Mar. 2011.

Davies, F.T., Jr. 1988. Influence of nutrition and carbohydrates on rooting of cuttings. Comb. Proc. Intl. Plant Prop. Soc. 38:432-437.

Dhua, R.S. and S.K. Sen. 1984. Role of etiolation, auxinic and non-auxinic chemicals on root initiation of air-layering of jack-fruit. Indian J. Hort. 41:116-119.

Dirr, A.M. and C.W. Heuser, Jr. 2006. The reference manual of woody plant propagation:
From seed to tissue culture. Varsity Press, Inc., NC.

Hartman, H.T., D.E. Kester, F.T. Davies, and R.L. Geneve. 2011. Hartmann and Kester's plant propagation: Principles and practices. 8th Ed. Prentice Hall, NJ.

Hartmann, H.T. 1969. Some physiological factors involved in propagations by hardwood cuttings. Proc. Intl. Pl. Prop. Soc. 19:108.

Hartmann, H.T., D. Kester, F.T. Davies, Jr., and R.L. Geneve. 2002. Plant propagation: Principles and practices. Pearson Education Inc., NJ.

Lancashire, R. 1995. Jamaican ackee. The Department of Chemistry, University of the West Indies, Mona Campus, Jamaica. <http://wwwchem. uwimona.edu.jm/lectures/ackee.html $>$.

Lancashire, R.J. 2004. The Jamaican national fruit. Dec. 2005. <http://www.chem.uwimona.edu.jm>.

Lewis, C.B. 1965. Carbon abundance in Chrondritic meteorites. Inform. Bull. Scientific Res. Council $1: 12-14$.

Lingarajappa, V.G. 1982. Studies on the effect of pretreatments and growth regulators on rooting of jack-fruit air-layering. Thesis Abstracts 8:174-175.

Llamas, K.A. 2003. Tropical flowering plants: A guide to identification and cultivation. Timber Press, Inc., Portland, OR.

Maiti, S.C. 1985. Fruits of India: Tropical and subtropical, p. 388-408. In: Bose, T.K. (ed.). Naya Prokash Publishers, Calcutta, India.

Morton, J.F. 1987. Fruits of warm climates. Miami, FL. p. 269-271.

Mukhopadhaya, T.P. 1986. Litchi, p. 285-295. In: Bose, T.K., S.K. Mitra, and M.K. Sadhu (eds.). Propagation of tropical and subtropical horticultural crops. Naya Prakash, Calcutta, India.

Rahman, M.N., M.N. Amin, M.S. Islam, M.M. Begum, and M.A. Uddin. 2002. Rooting and survival of air-layering in Litchi as influenced by layering time and plant growth regulators. Pak. J. Biol. Sci. 5:1259-1260.

Rahman, M.N., I. Hussaini, M. Imran, T. Jan, and A.A. Mwan. 2000. Effect of different concentrations of IBA on rooting of Litchi (Litchi chinensis) in air-layering. Pak. J. Biol. Sci. 3:330-331.

Taiz, L. and E. Zeiger. 2006. Plant physiology. $4^{\text {th }}$ Ed. Sinauer Associated, Inc., Sunderland, MA. 